Selcuk Journal of Agriculture and Food Sciences

http://sjafs.selcuk.edu.tr/sjafs/index

Research Article
SJAFS

(2021) 35 (3), 210-217

e-ISSN: $2458-8377$

DOI:10.15316/SJAFS.2021.250

\title{
Factors Affecting the Income of Farmers Participating In Traditional and Modern Livestock Markets: Case Study from Benin Republic
}

iD Oscar AKOUEGNONHOU ${ }^{1, *}$, iD Nevin DEMIRBAŞ ${ }^{2}$

${ }^{1}$ Ege University, Institute of Science, Department of Agricultural Economics, İzmir, Turkey

${ }^{2}$ Ege University, Faculty of Agriculture, Department of Agricultural Economics, İzmir, Turkey

\begin{tabular}{l}
\hline ARTICLE INFO \\
\hline Article history: \\
Received date: 24.04 .2021 \\
Accepted date: 19.10 .2021 \\
\hline
\end{tabular}

\section{Keywords:}

Livestock market

Household income

Multivariate regression

Benin Republic

\begin{abstract}
Livestock markets in pastoral areas of Africa are institutions that facilitate the marketing of animals and animal products. The income of farmers participating in these livestock markets is influenced by various social and economic factors. These factors are generally not considered by farmers when making their decisions. Knowledge and control of these factors will enable farmers to make rational decisions in the production and sale of their animals, and thus improve their income. It is in this context that this study aimed to determine the factors affecting the income of rural households engaged in animal husbandry in the Republic of Benin. Livestock production system in Benin has been mostly traditional. However, the system has been gradually modernized. The farmers have marketed their livestock and livestock products in two types of selfmanaged livestock markets which are "Marché à Bétail Autogéré" (MBA) as modern market and "Marché à bétails Traditionnel (MT) as traditional livestock markets. The data of the research were obtained from face-to-face surveys conducted with 300 farmers in livestock markets. Multivariate regression model was used to analyze the factors affecting rural household income. Model results show that the variables of education level, experience in livestock farming, access to credit, number of cattle, number of sheep, pasture use, access to veterinary services, and membership to a livestock organization had a significant positive effect on the incomes of farmers preferring the MBA livestock market. While the variables of experience in livestock farming, number of cattle, pasture use, farmland ownership, and number of sheep had a significant positive effect on the incomes of farmers preferring the MT livestock market.
\end{abstract}

\section{Introduction}

The development of many African countries' economy and life of the rural population in the south of the Sahara depends on the agricultural sector. Seventy to $80 \%$ of the active population was employed in the agricultural sector. The contribution of the agricultural sector to the Gross Domestic Product (GDP) of these countries ranged from $30 \%$ to $50 \%$. The rural population in these countries has lived under low life standards and in economically unfavourable conditions (Diallo, 2004). In Benin Republic, economic activities were predominantly based on agriculture, and the agricultural sector contributes about $32.5 \%$ to GDP, $75 \%$ to exports, $15 \%$ to tax revenues and about $70 \%$ to employment (FAO, 2018). Agriculture is then seen as a sector with many potentials that should be seriously exploited to support national economic growth and thus contribute to the effective fight against poverty.

\footnotetext{
* Corresponding author email: akbiggest@gmail.com
}

Livestock sub-sector occupies a significant place in agriculture and plays an important role in the economy of many African countries. Despite its traditional production system, it contributed $44 \%$ of the GDP of the Economic Community of West African States (ECOWAS) countries and ranked first in terms of trade in West Africa (Fabien, 2019).

The contribution of the livestock sub-sector to GDP of Benin was $5.82 \%$ and its share in the gross agricultural production value was $15.55 \%$ (FAO, 2016). It ranked second after crop production, and also contributes to agricultural services through fertilizer, traction and transport, especially in the cotton regions (ANOPER, 2014).

The animal species raised in Benin are conventional species (cattle, sheep, goats, pigs, poultry, etc.) as well as non-conventional species such as "Aulacode" (MAEP, 2001; ANOPER, 2014).

The animal production system is largely of the traditional nomadic and extensive type. This type of animal husbandry is based on the use of large areas, its main feature is the mobility of farmers and animals. 
This system is a way of effectively utilizing regional seasonal changes in feed and water resources, and these seasonal movements are sociologically important in some countries.

In West Africa countries, the poorest people depend on livestock as the main economic activity that provides them with food and cash. It is also the main insurance against risk for millions of poor people whose livelihoods depend on rain-fed agriculture. However, the region's potential for livestock production is poorly exploited (Roukayath, 2016; Fabien, 2019). Rural households do not fully benefit from the fruits of their activities and live on low incomes.

The income of the livestock farmers is mainly based on animal sale, which usually takes place in livestock markets. In the past, farmers in developing countries used to sell their animals in traditional markets when they need money in an emergency, but nowadays, most of them have moved into commercial production and also go to modern livestock markets. Some reasons for this change can be stated as improved animal prices and marketing margins in organized livestock markets, transaction flows in markets increase, etc. Animal markets constitute very important socioeconomic units in the Sahara countries. Livestock markets in rural areas can ensure the economic development of regions, thus increasing the income of both the rural population and municipalities.

In Benin, farmers have marketed their livestock and livestock products in two types of self-managed livestock markets which are "Marché à Bétail Autogéré" (MBA) as modern market and "Marché à bétails Traditionnel (MT) as traditional livestock markets.

Considering the importance of animal husbandry in the rural economy and its contribution to the incomes of rural households, it is crucial to deepen the scientific research in this sector in order to increase the incomes of rural households and improve their living conditions. Indeed, the income level of rural communities is attributed to certain crucial factors, and understanding and controlling these factors may be the key to effective rural development policy formulation (Adebayo, 1985).

A closer look at the determinants of rural income would provide an in-depth knowledge into the factors that explain low income yield and poverty in rural regions (Olatona, 2007).

An overview of some studies showed that various factors affect the income of rural communities. Onibon, (2004) identified the farm distance to livestock market and the intermediaries between seller and buyer as factors affecting negatively the income of livestock households in Benin. Fadipe et al. (2014) found that the level of education of the household head, the farm size, the access to electricity and the gender of the household head are the major determinants of the rural household income in kwara state, Nigeria.

Household asset endowments, demographic factors, accessibility to rural towns, migration opportunities and perceptions on food security were found by Alobo and Bignebat, (2017) as the main determinants of the rural household income in Senegal and Kenya. Safa, (2005) examined the farmers' income to be influenced by education, land area, livestock ownership, family size, and coffee cultivation, but not by the age of the farmer in Yemen. Coetzee et al. (2005) found that poor market infra-structure, price variability, limited marketing support services and market information and credit services, absence of effective producer organizations at the grassroots and limited access to markets provide inad-equate opportunities for increased incomes of cattle keepers in the Eastern Cape Province of South Africa. Mabe et al. (2010) showed that the herd size, the number of female farmers involved in livestock enterprises and the educational level of the household head affect positively the farm income in livestock producing communities of North-West Province in South Africa. Ndiaye, (2017) examined the factors that influenced rural household income and found that the level of education of the household head, the fattening, the size of the cultivated area, as well as the cultivation of tomatoes and sweet potatoes, are the most important factors that determine household income in Senegal.

This study therefore provides a very useful insight into the various factors that affect the income of the livestock households in the Republic of Benin. This would be very useful for the farmers themselves and will draw the attention of policy makers to improve efficiently the right determinants of rural household income. The objective of this study was to determine the factors affecting the household income of farmers preferring MT and those preferring MBA and to compare the results of the two types of livestock markets.

\section{Materials and Methods}

The main material of this study was obtained from face-to-face surveys conducted with livestock farmers in MBA and MT livestock markets in the Republic of Benin. The number of animal farmers interviewed within the scope of the research was determined as 300. To better compare the results, the 300 livestock farmers surveyed were divided into two groups: 150 farmers who preferred the MBA livestock market and 150 farmers who preferred the MT livestock market. In the field, the full list of MBAs has been taken from the Department of Livestock Management of the Ministry of Agriculture. Six MBA were selected, based on the existence of at least two MT in the municipality where each MBA is located. These are MBA of Gogounou, Nikki, Bassila, Matéri, Savè and Iwoyé. The animal farmers surveyed were randomly selected in each livestock market. However, attention has been paid to the fact that they participate in only one of the two types of livestock markets of each municipality. Either MBA or MT.

The multivariate regression model was used to determine the factors affecting rural household income (Hartono et al., 2011; Hartono and Rohaeni, 2014; 
Marwati et al., 2020). Rural household income is composed of farm income and off-farm income (Richard et al., 2016; Marwati et al., 2020).

The multivariate regression model is as follows:

$$
Y=\beta_{\mathrm{o}}+\beta_{1} X_{1}+\ldots+\beta_{\mathrm{n}} X_{\mathrm{n}}+\varepsilon,(\text { Şeref et al., 2016) }
$$

Table 1

Variables used in the model for MBA and MT livestock markets

\begin{tabular}{lll}
\hline Variables & Variable Description & Variable Type \\
\hline Age & Age of the farm owner (years) & Continuous \\
Education level & Formal education period (years) & Continuous \\
Experience in livestock farming & Experience in raising animal (years) & Continuous \\
Access to credit & Farmer' access to credits (0: no, 1: yes) & Dummy \\
Number of cattle & Number of cattle owned (number) & Continuous \\
Number of sheep & Number of sheep owned (number) & Continuous \\
Pasture use & Use of grazing land (0: no, 1: yes) & Dummy \\
Access to veterinary services & Farmer's access to veterinary services (0: no, 1: yes) & Dummy \\
Membership to a livestock organization & Membership to a animal husbandry organization (0: no 1: yes) & Dummy \\
Number of family members & Number of individuals in the family (person) & Continuous \\
Distance to market & The farm distance to market (km) & Continuous \\
Agricultural land ownership & Agricultural lands owned by the famer (ha) & Continuous \\
\hline
\end{tabular}

Y: Dependent variable

$\mathrm{X}_{\mathrm{i}}$ : Independent variables

$\mathrm{B}_{\mathrm{i}}$ : Parameters to forecast

$\varepsilon$ : Term of error

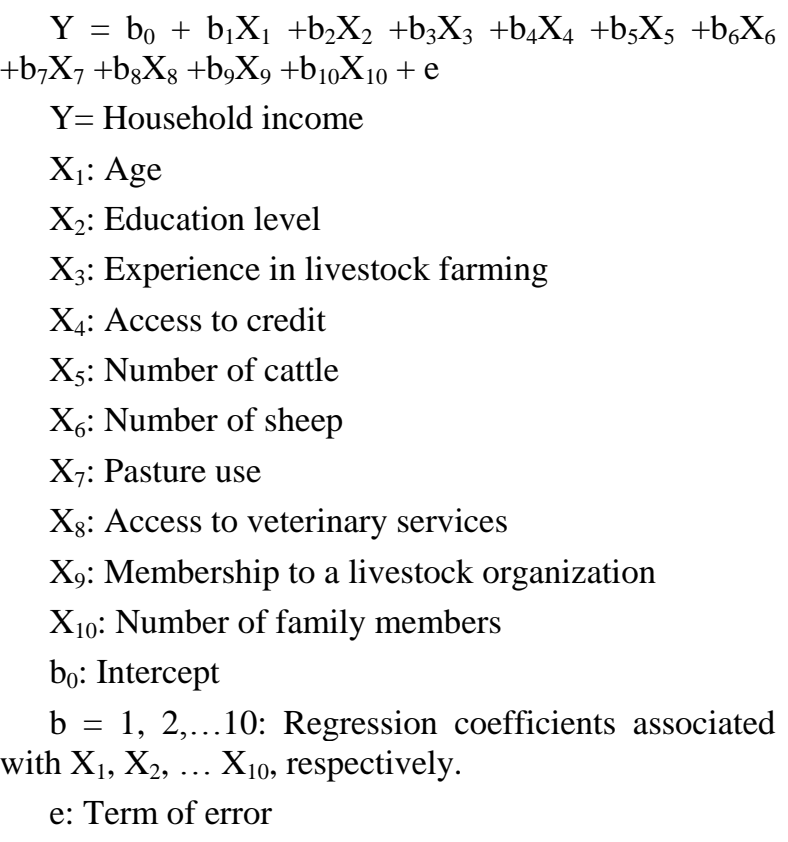

The OLS is the estimation method used in the regression models created to determine the factors affecting the household income of livestock farmers preferring MBA and MT livestock markets.

The White test was used to detect the difference of variance problem in the model, and the Variance Inflation Factor (VIF) was used to detect the multicollinearity problem (Marwati et al., 2020). It has been found that there is no difference of variance and no multicollinearity problems in the multiple linear regression model selected.

\section{Results and Discussion}

General Characteristics of the Farms and Farmers in $M B A$ and in MT Livestock Markets
Most of the farmers interviewed in this study $(97.67 \%)$ in both markets were men and only $2.33 \%$ were women. Men are generally head of the households and owners of the herd; their sons are shepherds; their wife has the right to milk the herd and sell it. Of the farmers, $45.33 \%$ are between 41-60 years old, followed by those $(43.34 \%)$ who are between $21-40$ years old. The education level of the farmers is low. The largest group $(76 \%)$ of the farmers in both markets had a primary education level. Farmers in MBA market had the highest education level. Most of the farmers have a farmland between 3-4 ha followed by those who have a farmland less or equal to 2 ha. The family size of $40 \%$ of the farmers is less than or equal to 3 members, followed by those $(38.6 \%)$ who have a family size between 4-7 members. Of the farmers, $49.67 \%$ have more than 21 years of experience in livestock farming. Most of the farmers have been involved in animal husbandry since childhood (Table 2).

\section{Livestock Farming System}

Livestock farming system in Africa is mostly extensive (traditional). The intensive system is still not much developed. Most of the West African countries have a grazing system. Livestock production in Benin is conducted predominantly as family production system. It is applied with a minimum monetary investment. This livestock farming is currently evolving into a mixed crop-livestock system under the influence of cotton cultivation and the introduction of certain food products (Roukayath, 2016).

Factors Affecting the Household Income of Livestock Farmers

In the model for determining the factors affecting the rural household income, 10 variables for MBA livestock markets and 9 variables for MT livestock markets were considered as independent variables. 
Table 2

Descriptive statisctics results for the livestocks farms

\begin{tabular}{|c|c|c|c|c|c|c|c|c|}
\hline & \multicolumn{2}{|c|}{ MBA } & \multicolumn{2}{|c|}{ MT } & \multicolumn{2}{|c|}{ General } & \multirow[b]{2}{*}{$\chi^{2}$} & \multirow[b]{2}{*}{$\mathrm{Sig}$} \\
\hline & Number & $\%$ & Number & $\%$ & Number & $\%$ & & \\
\hline \multicolumn{9}{|l|}{ Gender } \\
\hline Male & 147 & 98.0 & 146 & 97.3 & 293 & 97.67 & 0.084 & 0.92 \\
\hline Female & 3 & 2.0 & 4 & 2.7 & 7 & 2.33 & & \\
\hline Total & 150 & 100.0 & 150 & 100.0 & 300 & 100.0 & & \\
\hline \multicolumn{9}{|l|}{ Age } \\
\hline $21-40$ & 90 & 60.0 & 40 & 26.7 & 130 & 43.34 & 4.90 & 0.30 \\
\hline $41-60$ & 48 & 32.0 & 88 & 58.7 & 136 & 45.33 & & \\
\hline$>61$ & 12 & 8.0 & 22 & 14.7 & 34 & 11.33 & & \\
\hline Total & 150 & 100.0 & 150 & 100.0 & 300 & 100.0 & & \\
\hline \multicolumn{9}{|l|}{ Education (year) } \\
\hline Uneducated $(<1)$ & 3 & 2 & 63 & 42 & 66 & 22 & 27.07 & 0.86 \\
\hline $\begin{array}{l}\text { Primary school } \\
(1-6)\end{array}$ & 142 & 94.7 & 86 & 57.3 & 228 & 76 & & \\
\hline College $(7-10)$ & 5 & 3.3 & 1 & 0.7 & 6 & 2 & & \\
\hline Total & 150 & 100.0 & 150 & 100.0 & 300 & 100 & & \\
\hline \multicolumn{9}{|l|}{ Land size (ha) } \\
\hline$<2$ & 63 & 42.0 & 18 & 12.0 & 81 & 27 & 11.56 & 0.24 \\
\hline $3-4$ & 60 & 40.0 & 30 & 20.0 & 90 & 30 & & \\
\hline $5-6$ & 25 & 16.7 & 48 & 32.0 & 73 & 24.33 & & \\
\hline$>7$ & 2 & 1.3 & 54 & 36.0 & 56 & 18.67 & & \\
\hline Total & 150 & 100.0 & 150 & 100.0 & 300 & 100 & & \\
\hline \multicolumn{9}{|l|}{ Household Size } \\
\hline$\leq 3$ & 94 & 62.7 & 26 & 17.3 & 120 & 40 & 8.30 & 0.22 \\
\hline $4-7$ & 44 & 29.3 & 72 & 48.0 & 116 & 38.67 & & \\
\hline $8-11$ & 12 & 8.0 & 51 & 34.0 & 63 & 21 & & \\
\hline$\geq 12$ & - & - & 1 & 0.7 & 1 & 0.33 & & \\
\hline Total & 150 & 100.0 & 150 & 100.0 & 300 & 100 & & \\
\hline \multicolumn{9}{|l|}{ Experience (year) } \\
\hline$\leq 5$ & 5 & 3.3 & 8 & 5.3 & 13 & 4.33 & 6.21 & 0.72 \\
\hline $6-10$ & 25 & 16.7 & 33 & 22.0 & 58 & 19.33 & & \\
\hline $11-20$ & 41 & 27.3 & 39 & 26.0 & 80 & 26.67 & & \\
\hline$\geq 21$ & 79 & 52.7 & 70 & 46.7 & 149 & 49.67 & & \\
\hline Total & 150 & 100.0 & 150 & 100.0 & 300 & 100 & & \\
\hline
\end{tabular}

The Self-Managed Livestock Market (MBA)

Based on the results of the multicollinearity test, it was found that there was no difference of variance (White Test: 0.994) and no multicollinearity problems in the model developed for determining the factors

Table 3

Multicollinearity Test Results affecting the household income of livestock farmers preferring MBA livestock markets.

The VIF value in each variable is less than 10 and the tolerance value is greater than 0.10 , then it can be said that the regression model is free from multicollinearity problems (Table 3).

\begin{tabular}{lcc}
\hline Variables & Tolerance & VIF \\
\hline Constant & & 1.360 \\
Age & 0.735 & 4.472 \\
Education level & 0.224 & 1.787 \\
Experience in livestock farming & 0.560 & 1.849 \\
Access to credit & 0.541 & 1.335 \\
Number of cattle & 0.749 & 1.480 \\
Number of sheep & 0.676 & 1.905 \\
Pasture use & 0.525 & 1.336 \\
Access to veterinary services & 0.748 & 4.213 \\
Membership to a livestock organization & 0.237 & 1.218 \\
Number of family members & 0.821 & \\
\hline
\end{tabular}

The F test was used to determine whether the independent variables in the model had a significant effect on the dependent variable simultaneously.

In Table $4, \mathrm{~F}$ and its signigicance were found as 107.964 and $=0.000$, respectively. About ninety (0.901) percent of variance in the household income of the farmers can be explained by the explanatory variables included in the MBA model. The independent variables of age, education level, experience in livestock farming, access to credit, number of cattle, number of sheep, pasture use, access to veterinary services and membership to a livestock organization have statistically significant positive impact on the household income of the farmers preferring the MBA livestock markets. 
The results showed that age of the household head and the number of family members have no statistically significant impact on the income of farmers participating in MBA. Eductaion level has a statistically significant positive impact on the rural household income of farmers. This result is similar to that obtained by Hartono and Rohaeni, 2014; Awan et al., 2015; Kabir et al., 2019; Marwati et al., 2020 who have shown in their studies that a higher level of education of the household head leads to an increase in farm income as it enables efficient decision making.

Experience in livestock farming has a statistically significant positive impact on the rural household income of farmers. This indicates that a high experience in livestock production might lead to a high household income. Farmers with a high experience would be more efficient in decision-making. This result is in line with previous studies conducted by Thys et al. (2005) in Ouagadougou in Burkina Faso and Ndiaye, (2017) in Senegal who have showed that a high farming experience would be related to a high household income.

Access to credit has a statistically significant positive impact on the income of farmers. Credit is a source of financing for agricultural activities.

Number of cattle has a statistically significant positive impact on the income of farmers. Cattle raising is the first choice of pastoralists. The size of the cattle herd determines the level of their household income. Safa, (2005) found in his study in Yemen that agroforestry farmers with livestock had high family income compared to those with less or no livestock. Number of Table 4

Model results for determining the factors affecting the household income of the farmers preferred MBA

\begin{tabular}{|c|c|c|c|c|}
\hline Variables & Coefficient & Standard error & t-statistic & p-value \\
\hline Constant & 0.859 & 0.854 & 1.005 & 0.317 \\
\hline Age & 0.090 & 0.068 & 1.324 & 0.188 \\
\hline Education level & 0.097 & 0.046 & 2.095 & $0.039 * *$ \\
\hline Experience in livestock farming & 0.109 & 0.058 & 1.867 & $0.065^{*}$ \\
\hline Access to credit & 0.386 & 0.104 & 3.722 & $0.000 * * *$ \\
\hline Number of cattle & 0.629 & 0.095 & 6.631 & $0.000 * * *$ \\
\hline Number of sheep & 0.103 & 0.056 & 1.844 & $0.068 *$ \\
\hline Pasture use & 0.482 & 0.082 & 5.852 & $0.000 * * *$ \\
\hline Access to veterinary services & 0.555 & 0.124 & 4.489 & $0.000 * * *$ \\
\hline Membership to a livestock organization & 0.616 & 0.094 & 6.574 & $0.000 * * *$ \\
\hline Number of family members & -0.072 & 0.094 & -0.761 & 0.449 \\
\hline
\end{tabular}

sheep has a statistically significant positive impact on the income of farmers. Most of pastoralists of the sudy area associate cattle with small ruminant, mostly sheep. Sheep ranks second after cattle. It contributes significantly to the household income especially during festivals (Thys et al. 2005; Medenou, 1992).

Pasture use has a statistically significant positive effect on the income of farmers. The grazing lands used by most of farmers in pastoral areas are mostly natural, ungrown. This is costless for them. Pastoral livestock production is mainly derived from the use of natural resources - grassland and shrubs - grazed by animals on uncultivated lands mainly in arid and semi-arid areas (CEDEAO, 2008). This result is similar to that of Marandure et al. (2016) who stated that natural pasture feed resources reduce production costs, which subsequently improves the volume and quality of marketable livestock and therefore increases household income.

Access to veterinary services has a statistically significant positive impact on the income of farmers. Veterinary services are much useful for farmers to control the health of their husbandary by keeping them in a good state and protect them especially against Tripanosomia during rainy seanson.

Membership to a livestock organization has a significant positive impact on the income of farmers. To benefit from the advantages of livestock markets such as training, price information, loans, etc., most of farmers participating in MBA markets are part of existing livestock farmer organization in their area.

\section{$\mathrm{X}_{9}$ : Age}

$\mathrm{b}_{0}$ : Intercept

$\mathrm{b}=1,2, \ldots 9$ : Regression coefficients associated with $\mathrm{X}_{1}, \mathrm{X}_{2}, \ldots \mathrm{X}_{9}$, respectively.

e: Term of errorBased on the results of the multicollinearity test, there was no difference of variance (White Test: 0.134 ) and no multicollinearity problems in the model developed for determining the factors affecting the household income of livestock farmers who preferred MT livestock markets.

Table 5 shows that the VIF value in each variable is less than 10 and the tolerance value is greater than 
0.10 , then it can be said that the regression model is

Table 5

Multicollinearity Test free from multicollinearity problems.

$\begin{array}{ll}\text { Tolerance } & \text { VIF } \\ 0.947 & 1.056 \\ 0.933 & 1.072 \\ 0.837 & 1.195 \\ 0.737 & 1.357 \\ 0.276 & 3.623 \\ 0.313 & 3.198 \\ 0.950 & 1.053 \\ 0.371 & 2.698 \\ 0.273 & 3.666\end{array}$

The $\mathrm{F}$ test was used to determine whether the independent variables in the model had a significant effect on the dependent variable simultaneously.Table 6 shows that $\mathrm{F}$ and its significance were found 94.256 and 0.000 , respectively. Explanatory variables explained $88 \%$ of variance in the income of livestock farms. Except membership to a livestock organization, distance to market, Number of family members, and age, the independent variables of experience in livestock farming, number of cattle, pasture use, agricultural land ownership and number of sheep significantly and positively affected the income of the farmers preferring the MT livestock markets.

Experience in livestock farming has a statistically significant positive impact on the rural household income of farmers in MT. This indicates that a high level of experience in livestock production leads to a high household income. Farmers with a high experience would be more efficient in decision-making. This result is in line with previous studies conducted by Thys et al. (2005) in Ouagadougou in Burkina Faso; Ndiaye, (2017) in Senegal.

Number of cattle has a statistically significant positive impact on the income of farmers. The size of the cattle herd determines the level of household income. Safa, (2005) stated in his study that agroforestry farmers with livestock had high family income compared to those with less or no livestock in Yemen.

Pasture use has a statistically significant positive effect on the income of farmers. The grazing lands used Table 6

Model results for determining the factors affecting the household income of the farmers who prefer MT

\begin{tabular}{|c|c|c|c|c|}
\hline Variables & Coefficient & Standard error & t-statistic & p-value \\
\hline Constant & 0.370 & 1.010 & 0.367 & 0.715 \\
\hline Membership to a livestock organization & 0.307 & 0.240 & 1.281 & 0.203 \\
\hline Experience in livestock farming & 1.435 & 0.377 & 3.811 & $0.000 *$ \\
\hline Number of cattle & 0.110 & 0.045 & 2.446 & $0.016 * *$ \\
\hline Distance to market & 0.008 & 0.057 & 0.143 & 0.887 \\
\hline Pasture use & 1.121 & 0.219 & 5.109 & $0.000 *$ \\
\hline Agricultural land ownership & 0.838 & 0.095 & 8.850 & $0.000 *$ \\
\hline Number of family members & -0.004 & 0.050 & -0.083 & 0.934 \\
\hline Number of sheep & 0.778 & 0.156 & 4.983 & $0.000 *$ \\
\hline Age & -0.071 & 0.093 & -0.766 & 0.346 \\
\hline $\begin{array}{ll}\mathrm{R}^{2}: 0.890 & \text { F value: } 94.256 \\
\text { Adjusted } \mathrm{R}^{2}: 0.880 & \text { p-value: } 0.000\end{array}$ & & & & \\
\hline
\end{tabular}

by most of farmers in the study areas are mostly natural, ungrown. This is costless for them. Pastoral livestock production is mainly derived from the use of natural resources - grassland and shrubs - grazed by animals on uncultivated land mainly in arid and semiarid areas (CEDEAO, 2008). This result was also found by Marandure et al. (2016) who stated that natural pasture feed resources reduce production costs, which subsequently improves the volume and quality of marketable livestock and therefore increases household income.

Agricultural land ownership has a statistically significant positive impact on the income of farmers. The ownership of agricultural land procure many advantages to livestock farmers who live in deeper local areas. Safa, (2005) found that land size owned is significantly positively related to farmers' income in Yemen Ndiaye, (2017) showed that agricultural area has a positive and significant effect on the household income in Senegal. It is then assumed that if farm size increases, the share of income from the farm income source would also increase.

Number of sheep has a statistically significant positive impact on the income of farmers. Most of pastoralists of the sudy area associate cattle with small ruminant, mostly sheep. Sheep ranks second after cattle. It contributes significantly to the household income especially during festivals (Thys et al. 2005; Medenou, 1992). 


\section{Conclusion}

In the monetary approach, the life standard indicator is household income. A household income derives from many activities (EMICoV, 2015). In most African countries, household income derives from agriculture and livestock sub-sector is a source of income for many rural households. In most of sub-Saharan Africa, it appears that livestock farming is practiced for subsistence, food, risk reduction, traction, fertilizer and cash income (Beverly et al., 2008).

The aim of this study was to determine the factors affecting the household income of farmers engaged in animal husbandry in the Republic of Benin. Two types of animal markets (MBA and MT) were considered in this study.

According to the results, many social and economic factors have a statistically significant positive impact on the household income of farmers participating in MBA and MT livestock markets. Experience in livestock farming, number of cattle, number of sheep, pasture use have a statistically significant positive impact on the household income in both MBA and MT livestock markets, while education level, access to credit, veterinary services, membership to a livestock organization have a statistically significant positive impact on only the household income of farmers participating in MBA and agricultural land ownership has a statistically significant positive impact on only the household income of farmers participating in MT.

Those factors, when they are improved efficiently, they can enable farmers to increase their household income and reduce the poverty in rural areas in the Republic of Benin. Income determinants should be carefully integrated in rural development policies in order to improve the rural household's purchasing power as well as the income distribution in the study area.

Enhancing access to credits, promoting rural education and road conditions and empowering rural households to make rational decision in selling their animals in a well-organized livestock market will reduce negative livestock income and consequently improve income of poor household in the rural areas, especially in the pastoral regions in Africa. In addition, priorities should be given to the development of large and modern livestock farming, and to modern livestock marketing system like Self-Managed Livestock Markets (MBA).

The government should therefore invest in the education and training of young people in the rural areas to encourage and provide them with the knowledge and skills necessary to improve their living conditions and alleviate poverty. Producers' easy access to farmland would allow them to increase their crop area and livestock, which would be a good policy for improving their household income.

The government should also encourage farmers' organizations that can promote their identity and repre- sent their interests to the public authorities. Again, access to credit should be facilitated by the public administration to enable farmers to finance their activities.

In addition, women should be encouraged to participate more intensively in agricultural activities to reduce income inequality and poverty.

\section{References}

Adebayo AF (1985). The Implications of Community Leadership for Rural Development Planning in Nigeria. Community Development Journal, 20, 24-31, 1985.

Alobo S and Bignebat C (2017). Patterns and determinants of household income diversification in rural Senegal and Kenya. Journal of Poverty Alleviation and International Development, 2017, 8 (1), pp.93126.

ANOPER (2014). La situation actuelle de l'élevage et des éleveurs de ruminants au Bénin: analyse et perspectives. 68p.

Awan AG, Faridi MZ and Abbas MM (2015). Factors Affecting Women Contribution in Household Budget in Urban Informal Sector: An Analysis. Global Journal of Human Social Science Volume XV Issue II Version I.

Beverly D M, Hans RH, Judi W and Robert TW (2008). International assessment of agricultural knowledge, science and technology for development (IAASTD): Sub-Saharan Africa (SSA) report.

CEDEAO (2008). Élevage et marché régional au Sahel et en Afrique de l'Ouest Potentialités et défis.

Coetzee L, Montshwe BD and Jooste A (2005). The marketing of livestock on communal lands in the Eastern Cape Province: constraints, challenges and implications for the extension services. South African Journal of Agricultural Extension 34: 81-103.

Diallo B (2004). Analyse historique de l'organisation professionnelle et de la dynamique du développement des systèmes d'élevage en France. Enseignements et propositions pour la professionnalisation du Secteur de l'élevage subsaharien (Afrique Ouest et du Centre). Mémoire de fin d'études. 97 pp.

EMICoV (2015). Enquête modulaire intégrée sur les conditions de vie des ménages 3ème édition, rapport préliminaire.

Fabien T (2019). Dynamiques régionales des filières d'élevage en Afrique de l'Ouest. Etude de cas centré sur la côte d'ivoire dans le bassin commercial central.44pp.

Fadipe AEA, Adenuga AH and Lawal A (2014). Analysis of Income Determinants among Rural Households in Kwara State, Nigeria.

FAO (2016). Revue des filières bétail/viande \& lait et des politiques qui les influencent au Bénin. $76 \mathrm{pp}$. 
FAO (2018). Profil National Genre des Secteurs de l'Agriculture et du Developpement Rural - Bénin. Serie des Évaluations Genre des Pays. Cotonou. $148 \mathrm{pp}$.

Hartono B and Rohaeni ES (2014). Contribution to income of traditional beef cattle farmer households in Tanah Laut Regency, South Kalimantan, Indonesia Livest. Res.Rur. Dev. (8):1-9.

Hartono B, Ningsih UW and Septiarini NF (2011). The consumers'behavior in purchasing meatballs in Malang, Indonesia. Buletin Paternakan UGM. Vol. 35(2): 136-141.

Kabir MS, Markovi'c MR and Radulovi'c D (2019). The Determinants of Income of Rural Wome in Bangladesh. Sustainability 2019, 11, 5842; doi: 10.3390/su11205842.www.mdpi.com/journal/sustai nability

Mabe LK, Antwi MA and Oladele OI (2010). Factors influencing farm income in livestock producing communities of North-West Province, South Africa.

MAEP (2001). Etat des ressources zoogénétiques rapport national présenté par le CCN.71pp.

Marandure T, Mapiye C, Makombe G, Nengovhela B, Strydom P, Muchenje V and Dzama K (2016). Determinants and opportunities for commercial marketing of beef cattle raised on communally owned natural pastures in South Africa, African Journal of Range \& Forage Science, 33:3, 199-206, DOI: 10.2989/10220119.2016.1235617

Marwati S, Rahajuni D, Supadi (2020). Factors Affecting Income of Female Workers Producing Ketupat Casing and Their Contribution to Household Income. EKO-REGIONAL, Vol 15, No. 1, Maret 2020. pp. 44-52.

Medenou C (1992). Etude technique et e'conomique de l'embouche ovine urbaine et pe'ri-urbaine dans les régions de Ouagadougou et de Kongoussi (Burkina
Faso). Rapport de stage DESS. IEMVT, MaisonsAlfort.

Ndiaye M (2017). Déterminants du revenu agricole des ménages au delta du fleuve Sénégal. Rev. Ivoir. Sci. Technol., 30 (2017) 281 - 290. ISSN 18133290,http://www.revist.ci

Olatona MO (2007). Agricultural Production and Farmers Income in Afon District, Unpublished B.Sc. Project, Department of Geography, University of Ilorin.

Onibon P (2004). Rapport de synthèse de l'atelier de Ouagadougou <<stratégie à bétail autogéré au Nord du Bénin $>>$ Ouagadougou, 15p.

Richard D, Alary V, Corniaux C, Duteurtre G, Lhoste $P$ (2016). Dynamique des élevages pastoraux et agropastoraux en Afrique intertropicale.

Roukayath CT (2016). Place de l'elevage bovin dans l'economie rurale des peuls du nord Bénin. Dissertation originale présentée en vue de l'obtention du grade de docteur en sciences agronomiques et ingénierie biologique.

Safa MS (2005). Socio-Economic Factors Affecting the Income of Small-scale Agroforestry Farms in Hill Country Areas in Yemen: A Comparison of OLS and WLS Determinants. Small-scale Forest Economics, Management and Policy, 4(1): 117-134, 2005.

Şeref K, Ali Sait A, Abdullah E, Engin K, Belma A, Meltem K, Hidayet ÜK, Eda UÇ, Aliye K, Ömer LA, Nezihe U, Hakan D, Didar Bİ and Onur S (2016). SPSS uygulamalı çok değişkenli istatistik teknikleri, ISBN: 975-9091-14-3, 7.Bask1.

Thys E, Oueadraogo M, Speybroeck N and Geerts S (2005). Socio-economic determinants of urban household livestock keeping in semi-arid Western Africa. 